\title{
HUBUNGAN PEMANFAATAN HASIL PENELITIAN DENGAN PENULISAN TESIS JURUSAN ILMU-ILMU PERTANIAN \\ TAHUN 2004-2006 DI PERPUSTAKAAN FAKULTAS PERTANIAN \\ UGM YOGYAKARTA
}

\begin{abstract}
Ishartati*
Abstract

This research aims to know the correlation between research outcome and the process of thesis writing on agriculture science from about 2004-2006 at the Faculty of Agriculture Gadjah Mada University Yogyakarta. This is an explanatory research which tries to investigate the causality relationship between dependent variable "the use of the research outcome" and independent variable "the process of thesis writing" by university students about 2004-2006 on agriculture science.

The Research uses primary and secondary data, the primary data use 10 items of questionnairre for independent variable and 10 items of questionnarre for dependent variable. The data was collected from 44 respondents, and all of the respondents are valid to be analysed. The Secondary data are based on statistical data from library of Agriculture Faculty Gadjah Mada University. The data collected were analysed by using quantitative method of regression analysis.

The analysis of the research shows that: the use of research outcome has a positive and significant relation on the process of thesis writing. The relation can be seen from p-value numbering at $0.000(<0.005)$. while determination coefficient is by $35,7 \%$, which can known from adjusted $R 2$ are 0.357 . this mean that $64,3 \%$ are influenced from other variables.
\end{abstract}

Keywords: Academic collection, The use of research

*) Pustakawan UGM ditempatkan di PAU Pangan dan Gizi

\section{PENGANTAR}

Perpustakaan berfungsi sebagai sumber belajar dan sumber informasi bagi pemustaka. Agar sumber informasi itu optimal pemanfaatannya, maka perlu pengelolaan sesuai dengan ilmu perpustakaan. Sulistyo Basuki (1991:27) mengemukakan eksistensi perpustakaan dalam masyarakat harus tetap dipertahankan, karena perpustakaan mempunyai fungsi yang berkaitan dengan kepentingan masyarakat yakni antara lain sebagai fungsi informasi dan fungsi penelitian.

Jenis pemanfaatan hasil penelitian tersebut dapat digunakan sebagai bahan acuan dalam membuat suatu kebijakan atau kajian. Sebagai upaya memenuhi kebutuhan hasil penelitian sekarang ini sudah terpenuhi dan jumlahnya sudah mencukupi, sedangkan pemanfaatan hasil-hasil penelitian belum termaksimalkan fungsi dan kegunaannya. Setelah penelitian dilaksanakan maka di akhir masa pelaksanaannya harus menulis hasil yang diperoleh dalam suatu karya penelitian untuk diserahkan kepada yang berkepentingan. Tugas penelitian baru memiliki manfaat apabila hasilnya bisa dibaca atau diketahui oleh orang lain dan dipublikasikan baik dalam bentuk jurnal, buletin, atau media cetak lainnya.

Berdasarkan latar belakang masalah di atas, maka dapat dirumuskan masalah sebagai berikut adalah: Bagaimana hubungan pemanfaatan hasil penelitian terhadap penulisan tesis jurusan Ilmu-Ilmu Pertanian Tahun 2004 2006 di Perpustakaan Fakultas Teknologi Pertanian UGM Yogyakarta?

Hipotesis penelitian sebagai berikut: "Apabila hubungan pemanfaatan hasil penelitian positif, maka penulisan tesis akan meningkat. Sebaliknya bila hubungan tersebut negatif, maka penulisan tesis akan menurun". 


\section{LANDASAN TEORI}

\section{A. Perpustakaan Perguruan Tinggi}

Menurut Sulistya-Basuki (1993 : 51-52), Perpustakaan Perguruan Tinggi ialah perpustakaan yang terdapat pada perguruan tinggi, badan bawahannya, maupun lembaga yang berfasilitas dengan perguruan tinggi, dengan tujuan utama membantu perguruan tinggi mencapai tujuannya. Yang termasuk perpustakaan perguruan tinggi ialah perpustakaan jurusan, bagian, fakultas, universitas, institut, sekolah tinggi, politeknik, akademi, maupun perpustakaan program non gelar. Ditinjau dari segi fungsi saja perpustakaan perguruan tinggi dengan perpustakaan sekolah berlainan. Kalau pada perpustakaan sekolah, pustakawan merupakan jembatan antar guru dengan murid maka pada perpustakaan perguruan tinggi terdapat bentuk yang berlainan, karena mahasiswa sudah dianggap mandiri dalam hal bacaan, penelusuran informasi, maupun kegiatan membaca lainnya.

Pada perpustakaan perguruan tinggi terdapat ciri khas yaitu adanya hubungan segi tiga antara pustakawan, mahasiswa, dan pengajar. Hubungan segi tiga ini menunjukkan bahwa mahasiswa, dan pengajar, berhubungan langsung dengan pustakawan dalam hal mencari informasi dan penelusuran informasi. Karena sifat hubungan langsung ini maka pustakawan perguruan tinggi haruslah orang yang ahli dalam subjek ditambah pendidikan kepustakawanan yang sesuai dengan standar profesi pustakawan. Hal ini membawa implikasi bahwa pustakawan perguruan tinggi harus mampu membantu mahasiswa menggunakan pustaka untuk kepentingan mahasiswa. Pada perpustakaan sekolah, pustakawan merupakan jembatan antara guru dengan murid karena pustakawan dapat bertindak selaku guru dalam pemilihan bahan bacaan dan penelusuran informasi (Sulistyo Basuki, 1993: 76). Secara umum tujuan perpustakaan perguruan tinggi adalah :

a) Memenuhi keperluan informasi masyarakat perguruan tinggi, lazimnya staf pengajar dan mahasiswa. Sering pula mencakup tenaga administrasi perguruan tinggi. b) Menyediakan bahan pustaka rujukan (referensi) pada semua tingkat akademik, artinya mulai dari mahasiswa tahun pertama hingga ke mahasiswa program pasca sarjana dan pengajar.

c) Menyediakan ruangan belajar untuk pemustaka.

d) Menyediakan jasa peminjaman yang tepat guna bagi berbagai jenis pemakai.

e) Menyediakan jasa informasi aktif yang tidak saja terbatas pada lingkungan perguruan tinggi tetapi juga lembaga industri lokal.

Dalam berbagai terbitan berupa direktori perpustakaan khusus, perpustakaan perguruan tinggi juga termasuk ke dalam kelompok perpustakaan khusus. Namun berdasarkan tradisi, perpustakaan perguruan tinggi digolongkan sebagai kelompok tersendiri (Sulistyo Basuki, 1993: 78).

\section{B. Pengertian Pemanfaatan}

Menurut Voight (1961: 44) bahwa tujuan pemanfaatan atau pemakaian sumber rujukan dapat dikelompokkan menjadi tiga yaitu:

1. Kebutuhan untuk tetap mengikuti perkembangan baru

2. Kebutuhan akan informasi spesifik yang secara langsung berhubungan dengan kegiatan penelitian atau masalah yang dihadapi.

3. Kebutuhan untuk mencari dan memeriksa informasi yang ada dan berhubungan dengan bidang yang diminati.

Penelitian Triana, Suni (2006: 27) yang berjudul Pemanfaatan Sarana Bibliografi Oleh Pustakawan yang dilakukan secara deskriptif melalui pendekatan kualitatif, dengan tujuan mengungkapkan fenomena pemanfaatan berbagai sarana bibliografis oleh pustakawan. Pengumpulan data dilakukan dengan menggunakan metode pengamatan, berperan serta, dan wawancara mendalam terhadap responden yang terdiri atas beberapa pustakawan. Sedangkan indikator pengukuran pemanfaatan hasil-hasil dari penelitian/karya ilmiah yang ada pada perpustakaan adalah 
1. Semaksimal mungkin dipergunakan oleh pemustaka perpustakaan sebagai bahan acuan penulisan ilmiah.

2. Dipublikasikan oleh instansi yang berkompeten terhadap hasil penelitian tersebut, baik dalam bentuk jurnal ilmiah maupun buku-buku.

3. Dijadikan bahan pengembangan disiplin suatu ilmu secara profesional, dan juga dapat dijadikan bahan pertimbangan pengambilan keputusan manajemen.

4. Pemustaka dapat mengakses hasil-hasil penelitian secara mudah, baik langsung datang ke perpustakaan maupun melalui internet.

5. Hasil-hasil penelitian dapat dijadikan bahan rujukan/referensi penelitian selanjutnya

\section{Koleksi Tesis}

Koleksi dalam Kamus Besar Indonesia berarti kumpulan. Tesis adalah jenis karangan ilmiah di tingkat $\mathbf{S} 2$, yang sifatnya lebih mendalam dari pada skripsi. Tesis umumnya merupakan laporan dari suatu penelitian yang dilakukan dengan seksama menurut metodologi riset di bawah bimbingan seorang (atau lebih) dosen sponsor yang bertanggung jawab dalam bidang itu (Surachmad $1971: 11$ ).

Koleksi tesis di dalam perpustakaan biasanya diletakkan di ruang referensi, beserta dengan koleksi referensi, koleksi cadangan dan koleksi lainnya. Koleksi tesis hanya bisa dibaca di tempat, tidak bisa dipinjam keluar. Hal ini untuk menghindari terjadinya plagiator.

\section{Teori Menulis Karya Ilmiah}

Kegiatan menulis merupakan kegiatan yang tidak terpisahkan dari empat keterampilan berbahasa yang meliputi keterampilan menyimak, berbicara, dan menulis (Tarigan, 2002; 1). Namun pada umumnya orang menganggap mengarang itu sesuatu pelajaran yang sulit. Anggapan tersebut disebabkan orang tampaknya lebih terbiasa melakukan kegiatan komunikasi secara lisan atau berbicara daripada kegiatan komunikasi tertulis atau mengarang.

Menurut Djuroto dan Suprijadi (2002) tulisan dibedakan menjadi 2 bentuk yaitu: artikel dan karya ilmiah. Artikel adalah tulisan tentang berbagai soal, mulai politik, sosial, ekonomi, budaya, olah raga, dan lain-lain, tanpa terikat dengan gaya bahasa dan format tulisan. Artikel bisa berbentuk fakta, interpretasi, atau opini. Sedangkan karya ilmiah adalah tulisan yang membahas suatu masalah. Pembahasan dilakukan berdasarkan penyelidikan, pengamatan, pengumpulan data yang didapat dari suatu penelitian, baik penelitian lapangan, tes laboratorium ataupun kajian pustaka. Langkahlangkah yang harus ditempuh untuk menulis biasanya tergantung dari kebiasaan penulis dalam mengawali suatu tulisan, antara lain:

1. Menentukan Topik.

2. Mengungkapkan Permasalahan

3. Menentukan Judul

Pengukuran keberhasilan dari suatu penulisan (tesis) dari segi idealistis bagi

mahasiswa S-2 adalah sebagai berikut: (Surachmad 1971):

1. Suatu hasil penulisan tesis konsekuensinya adalah harus mempunyai manfaat khusus bagi peneliti sendiri guna menambah wawasan dan menambah khazanah ilmu pengetahuan di bidang yang diteliti, baik itu dimaksudkan akan dipublikasikan ataupun tidak dipublikasikan.

2. Suatu hasil penulisan tesis diharapkan dapat dijadikan bahan ajar pada dunia pendidikan pada tingkatan ataupun bidang tertentu dan untuk menambah informasi tentang suatu hal.

3. Hasil penelitian yang baik, apalagi yang berkaitan dengan suatu profesi atau yang berkaitan dengan manajemen yang sifatnya strategis diharapkan dapat dijadikan bahan pertimbangan pengambilan keputusan.

4. Sebagai suatu hasil penelitian, jika hasil tersebut dijadikan suatu koleksi bahan pustaka, dapat dijadikan suatu data otentik pada perpustakaan yang dapat dimanfaatkan pemustaka.

5. Penulisan tesis yang berkaitan dengan suatu penelitian diharapkan dapat menjadi suatu bahan temuan baru yang bersifat ilmiah.

CARA PENELITIAN 
Penelitian ini termasuk jenis penelitian penjelasan (explanatory research), yang menjelaskan hubungan kausal antara variabel independen tersebut terhadap variabel dependen melalui pengujian hipotesis.

Populasi dalam penelitian ini adalah seluruh mahasiswa $S 2$ jurusan Ilmu- Ilmu Pertanian tahun 2005-2006 di Fakultas Teknologi Pertanian UGM Yogyakarta yang berjumlah 44 orang. Mengingat jumlah populasi ini relatif sedikit yaitu hanya 44 orang, maka untuk memperoleh data yang valid, peneliti menentukan besamya sampel sama dengan jumlah populasi yaitu sejumlah 44 orang mahasiswa.

Variabel Bebas (independent variable) dalam penelitian ini adalah pemanfaatan hasil penelitian $(X)$, sedangkan variabel tergantung (dependent variable) dalam penelitian ini adalah penulisan tesis $(\mathrm{Y})$.

Pengukuran variabelnya dilakukan dengan jalan mengajukan kuesioner kepada responden. Kuesioner atau daftar pertanyaan disusun dengan menerapkan Skala Likert, guna mengukur sikap, pendapat, dan persepsi seseorang atau sekelompok orang tentang variabel penelitian. Dengan Skala Likert, maka variabel yang akan diukur dijabarkan menjadi indikator variabel.

Metode analisis data dengan uji validitas merupakan uji homogenitas item pertanyaan per variabel untuk menunjukkan sejauh mana ketepatan dan kecermatan suatu alat ukur untuk melakukan fungsinya. Semakin tinggi validitas alat ukur maka semakin

kecil varian kesalahannya (Ghozali, 2003). Suatu kuesioner dikatakan valid jika pertanyaan pada kuesioner mampu untuk mengungkapkan sesuatu yang akan diukur oleh kuesioner tersebut. Untuk menguji validitas kuesioner digunakan rumus korelasi Product Moment Pearson

Uji reliabilitas merupakan kriteria tingkat kemantapan atau konsistensi suatu alat ukur (kuesioner). Suatu kuesioner dapat dikatakan mantap bila dalam pengukurannya secara berulang-ulang dapat memberikan hasil yang sama (dengan catatan semua kondisi tidak berubah). Untuk mengukur reliabilitas digunakan alat ukur dengan teknik Alpha Cronbach.

Keputusan reliabel tidaknya kuesioner dinyatakan apabila diperoleh nilai $r$ hitung $>r$ tabel dengan taraf signifikan 5\% $(0,005)$, maka butir pertanyaan tersebut dikatakan reliabel.

Pembuktian hipotesis dalam penelitian ini dilakukan melalui Uji-t dengan tingkat signifikansi 5\%. Uji-t di sini digunakan untuk membuktikan signifikansi pengaruh variabel terikat dengan langkah-langkah sebagai berikut (Sugiyono; 2004 : 181):

a) Menentukan $\mathrm{Ho}$ dan $\mathrm{Ha}$

Ho : $\mathrm{Bi}=0$ artinya Pemanfataan Hasil Penelitian tidak berhubungan secara

signifikan terhadap Penulisan Tesis.

$\mathrm{Ha}$ : Bi . 0 artinya Pemanfataan Hasil Penelitian berhubungan secara

signifikan terhadap Penulisan Tesis.

b) Level of significance (a) $=0,05$

c) Degree of freedom $=0,05 / 2$

Untuk mencari hubungan variabel independen dengan variabel dependen digunakan analisa regresi. Analisis regresi adalah studi mengenai ketergantungan variabel dependen dengan satu atau lebih variabel independen, dengan tujuan mengestimasi dan/atau memprediksi rata-rata populasi atau nilai ratarata variabel dependen berdasarkan nilai variabel independen yang diketahui (Gujarati, 2003:108). Hasil analisis regresi adalah berupa koefisien untuk masing-masing variabel independen. Koefisien ini diperoleh dengan cara memprediksi nilai variabel dependen. Dengan demikian persamaan regresi yang digunakan adalah:

$\mathrm{Y}=\mathrm{a}+\mathrm{bX}+\mathrm{e}$

Keterangan :

$\mathrm{a}=$ konstanta (intercept)

$\mathrm{Y}=$ Penulisan Tesis

$X=$ Pemanfataan Hasil Penelitian

$b=$ Koefisien regresi

$\mathrm{e}=$ random error

\section{HASIL DAN PEMBAHASAN}

Subjek penelitian adalah pemustaka yang tercatat sebagai mahasiswa S-2 FTP UGM yang berjumlah 44 orang. Kuesioner yang disebar berjumlah 44 buah. Dari jumlah itu kuesioner 
yang dikumpulkan kembali dan layak untuk digunakan adalah sebanyak 44 buah.

\section{A. Hasil Uji Validitas}

Untuk mengukur validitas digunakan uji korelasi bivariate antara masing-masing skor indikator dengan total skor konstruk, hasil pengujiannya diperoleh hasil validitas dari masing-masing variabel $\mathrm{X}$ dan $\mathrm{Y}$ menunjukkan valid semua, dan dari lampiran uji validitas variabel menunjukkan bahwa korelasi antara masing-masing indikator terhadap total skor konstruk menunjukkan hasil yang signifikan.

\section{B. Hasil Uji Reliabilitas}

Uji Reliabilitas terhadap variabel Pemanfaatan Hasil Peneliti (X) dan variabel Penulisan Tesis (Y), menunjukkan nilai Cronbach's Alpha untuk semua variabel bernilai lebih besar dari 0,6 yaitu 0,682 untuk Variabel Bebas dan 0,913 untuk Variabel Terikat. Menurut kriteria Nunally (Ghozali, 2005:44), apabila nilai Cronbach's Alpha > 0,6 maka dapat dikatakan reliabel.

\section{Uji Signifikansi Parameter Individual (Uji Statistik-t)}

Untuk menginterpretasikan koefisien variabel bebas (independen) dapat menggunakan unstandardized coefficients maupun standardized coefficients yang hasilnya menunjukkan bahwa variabel Pemanfaatan Hasil Penelitian (X) adalah positif dan signifikan. Hal ini dapat dilihat dari probabilitas signifikansi atau $p$-value untuk Pemanfaatan Hasil Penelitian (X) sebesar 0,000. Konstanta sebesar 4,562 menyatakan bahwa jika variabel independen dianggap konstan, maka Penulisan Tesis mempunyai nilai 4,562 satuan.

Dengan demikian dapat disimpulkan bahwa variabel Pemanfaatan Hasil Penelitian mempunyai hubungan positif dan signifikan terhadap Penulisan Tesis. Sehingga hipotesis Ha terbukti/diterima.

\section{Persamaan Regresi Linier Sederhana \\ Persamaan regresi sederhana yang menggambarkan pengaruh Pemanfaatan Hasil}

Penelitian terhadap Penulisan Tesis sebagai berikut:

$\mathrm{Y}=4,562+0,869 \mathrm{X}$

Keterangan :

$\mathrm{Y}=$ Penulisan Tesis

$\mathrm{X}=$ Pemanfaatan Hasil Penelitian

\section{E. Nilai Uji Koefisien Determinasi}

Dari tampilan output SPSS model summary, besarnya adjusted R2 adalah 0,357 , hal ini berarti $35,7 \%$ variabel Penulisan Tesis dijelaskan oleh variabel Pemanfaatan Hasil Penelitian, sedangkan sisanya $64,3 \%$ (100\%$35,7 \%$ ) dijelaskan oleh sebab-sebab yang lain diluar model/variabel tersebut.

\section{KESIMPULAN DAN SARAN}

\section{A. Kesimpulan}

Hasil penelitian berdasarkan perumusan masalah, tujuan dan hipotesis penelitian, dapat disimpulkan sebagai berikut :

1. Variabel Pemanfaatan Hasil Penelitian ada hubungan positif dan signifikan terhadap Penulisan Tesis, hal tersebut dibuktikan oleh nilai probabilitas signifikansinya atau p-value adalah 0,000 (lebih kecil dari 0,05). Dengan demikian hipotesis Ha terbukti.

2. Variabel Pemanfaatan Hasil Penelitian mempunyai hubungan sebesar $35,7 \%$ terhadap Penulisan Tesis. Hal tersebut diketahui dari nilai koefisien determinasi (adjusted R2) sebesar 0,357. Sedangkan sisanya sebesar $64,3 \%(100 \%-35,7 \%)$ dipengaruhi oleh variabel lain.

Dalam penelitian ini hanya terbatas meneliti Hubungan Pemanfaatan Hasil Penelitian yang ada di Perpustakaan Fakultas Teknologi Pertanian UGM terhadap Penulisan Tesis mahasiswa S-2 yang sedang menyusun tesis di Fakultas Teknologi Pertanian UGM, tidak meneliti seluruh mahasiswa S-2 di UGM.

\section{B. Saran}

1. Variabel Pemanfaatan Hasil Penelitian ada hubungan positif dan signifikan terhadap Penulisan Tesis, maka perlu adanya 
optimalisasi hasil-hasil penelitian, baik itu berupa tesis, jurnal ilmu pengetahuan, maupun hasil-hasil penelitian yang lain untuk dapat lebih dipublikasikan lebih luas.

2. Variabel Pemanfaatan Hasil Penelitian mempunyai hubungan sebesar $35,7 \%$ terhadap Penulisan Tesis. Ini berarti hasil penelitian mempunyai pengaruh yang masih sangat rendah terhadap penulisan tesis. Untuk itu perlu ada penelitian lebih lanjut mengenai pengaruh variabel lain selain hasil-hasil penelitian, misalnya: pengaruh literatur/buku, atau pengaruh informasi dari internet terhadap hasil penulisan tesis mahasiswa $\mathrm{S}-2$ di perguruan tinggi, dan lain-lain.

\section{DAFTAR PUSTAKA}

Arikunto, Suharsimi. 1999. Prosedur Penelitian Suatu Pendekatan Praktek. Jakarta: PT. Rineka Cipta.

Djuroto dan Suprijadi 2002. Menulis Artikel dan Karya Ilmuah, Bandung : PT. Remaja Rosdakarya

Ghozali, Imam. 2005. Aplikasi Analisis Multivariabel dengan Program SPSS. Badan Penerbit Universitas Diponegoro, Semarang.

Koentjoroningrat. 1990. Metodologi Penelitian . Yogyakarta: Pustaka Pelajar

Pendit, Putu Laxman 2003, Penelitian Ilmu Perpustakaan dan Informasi, Jakarta: PIP-FSUI.

Qolyubi, Syihabuddin dkk. , 2003. Dasar-Dasar Ilmu Perpustakaan Dan Informasi, Yogyakarta : Jurusan IPI Fakultas Adab UIN Sunan Kalijaga

Singarimbun, Masri dan Sofian Effendi. 1983. Metode Penilaian Survey, Jakarta: LP3ES.

Soehardjan. 1995. Metodologi Penelitian. Jakarta: Prestasi Pustaka.

Sugiyono. 2004. Metode Penelitian Bisnis. Bandung: Alfabeta.
Sulistyo-Basuki. 1993. Pengantar Ilmu Perpustakaan. Jakarta : PT. Gramedia Pustaka Utama

Supardi. 2005. Metodologi Penelitian Ekonomi \& Bisnis. UII Press, Yogyakarta.

Surachmad. 1994. Teori dan Macam-macam jenis Tulisan Ilmiah di Perguruan Tinggi. Yogyakarta: Andi

Triana, Suni, 2006. Pemanfaatan Sarana Bibliografi oleh Pustakawan. Jumal Perpustakaan. Vol 11

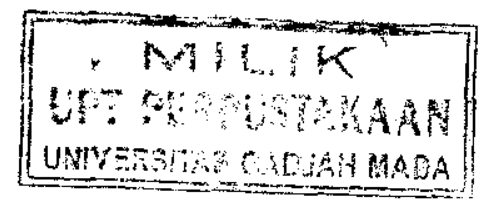

